\title{
The effects of dietary folate and zinc on the outcome of pregnancy and early growth in rats
}

\author{
By N. J. FULLER, P. H. EVANS, M. HOWLETT AND C. J. BATES* \\ MRC Dunn Nutritional Laboratory, Downhams Lane, Milton Road, Cambridge CB4 1XJ
}

(Received 13 July 1987 - Accepted 19 October 1987)

\begin{abstract}
1. The objective of the present study was to determine the effects of two levels of folic acid and two levels of zinc in the diets of rats during pregnancy and lactation. It addressed, among other things, the question of whether an inhibitory effect of folic (pteroylmonoglutamic) acid on $\mathrm{Zn}$ absorption might result in a secondary $\mathrm{Zn}$ deficiency in either the dams or the pups.

2. A purified diet was given to four groups of female DNL (Norwegian) Hooded rats, before and during pregnancy and during lactation. It contained the four possible combinations of: no added folic acid or $100 \mu \mathrm{g}$ added pteroylmonoglutamic acid $/ \mathrm{g}$, and 6.6 or $20.2 \mu \mathrm{g} \mathrm{Zn} / \mathrm{g}$. Pups and dams were killed on day 20 of gestation or on day 20 postpartum. Measurements of body-weights, food intakes, blood folate and tissue $\mathrm{Zn}$ levels were performed.

3. The group with low $\mathrm{Zn}$ and low folate intake had a satisfactory reproductive outcome, and there were only minor effects of the supplements on body-weights.

4. Additional folate greatly increased blood (erythrocyte and plasma) folate levels, but did not compromise tissue $\mathrm{Zn}$ concentrations. $\mathrm{Zn}$ supplementation also enhanced blood folate levels, for reasons which are not yet clear.

5. There was a moderate enhancing effect of the $\mathrm{Zn}$ supplement on $\mathrm{Zn}$ levels in the livers and kidneys of pregnant dams, and the kidneys of lactating dams.

6. If the conclusions can be extrapolated to humans, then the results provide some reassurance that a high folate intake from prenatal supplementation need not necessarily cause $\mathrm{Zn}$ depletion, and hence functional $\mathrm{Zn}$ deficiency in pregnant women and their offspring.
\end{abstract}

Zinc deficiency is endemic in many countries, and pregnant and lactating women and the neonate are among the most vulnerable groups (Simmer \& Thompson, 1985). Deficiency leads to growth retardation, together with functional and biochemical lesions. Folate deficiency is also widespread, especially during pregnancy, in many developing countries (Baumslag et al. 1970; Iyengar \& Rajalakshmi, 1975). There exists, at present, a widespread belief that folate supplements are generally beneficial and desirable for pregnant women; consequently they are commonly prescribed, together with iron supplements, yet $\mathrm{Zn}$ is rarely included.

Some recent studies have drawn attention to an important deleterious interaction between $\mathrm{Zn}$ and folic acid at the intestinal level, such that high intakes of folate (i.e. pteroylmonoglutamic acid supplements) may interfere with $\mathrm{Zn}$ absorption (Albert, 1953; Milne et al. 1984; McMaster et al. 1985; Ghishan et al. 1986; Simmer et al. 1987). This interaction, which is thought to be a direct physico-chemical one within the intestinal lumen, may limit the availability of dietary $\mathrm{Zn}$, but its possible results in terms of effects on Zn status have not yet been fully explored. Mukherjee et al. (1984) recorded fetomaternal complications and fetal distress associated with low plasma $\mathrm{Zn}$ and high plasma folate in human populations.

The purpose of the present study was to examine reproductive outcome, and anthropometric and biochemical indices of folate and $\mathrm{Zn}$ status, in pregnant and lactating rats fed on purified diets with two levels each of $\mathrm{Zn}$ and of folic (pteroylmonoglutamic) acid. 
Table 1. Composition of diets

\begin{tabular}{|c|c|c|c|c|}
\hline $\begin{array}{c}\text { Diet... } \\
\text { Ingredients }\end{array}$ & $\begin{array}{c}A^{*} \\
\text { (basal, low-Zn, } \\
\text { low-folate) }\end{array}$ & $\begin{array}{c}\text { B } \\
\text { (low-Zn, } \\
\text { high-folate) }\end{array}$ & $\begin{array}{c}\mathrm{C} \\
\text { (adequate- } \mathrm{Zn}, \\
\text { low-folate) }\end{array}$ & $\begin{array}{c}\mathrm{D} \\
\text { (adequate-Zn, } \\
\text { high-folate) }\end{array}$ \\
\hline New Zealand casein $(\mathrm{g} / \mathrm{kg})$ & 200 & 200 & 200 & 200 \\
\hline Arachis oil $(\mathrm{g} / \mathrm{kg})$ & 30 & 30 & 30 & 30 \\
\hline Cystine $(\mathrm{g} / \mathrm{kg})$ & $1 \cdot 5$ & 1.5 & 1.5 & 1.5 \\
\hline Choline chloride $(\mathrm{g} / \mathrm{kg})$ & $2 \cdot 0$ & $2 \cdot 0$ & $2 \cdot 0$ & $2 \cdot 0$ \\
\hline Sucrose $(\mathrm{g} / \mathrm{kg})$ & $716 \cdot 4$ & $716 \cdot 4$ & $716 \cdot 4$ & $716 \cdot 4$ \\
\hline Salt mixture ${ }^{\prime}(\mathrm{g} / \mathrm{kg})$ & $49 \cdot 8$ & $49 \cdot 8$ & $49 \cdot 8$ & $49 \cdot 8$ \\
\hline Vitamin mixture $\ddagger(\mathrm{g} / \mathrm{kg})$ & 0.33 & 0.33 & 0.33 & $0 \cdot 33$ \\
\hline $\begin{array}{l}\text { Added pteroylmonoglutamic acid } \\
(\mu \mathrm{g} / \mathrm{g})\end{array}$ & - & 100 & - & 100 \\
\hline Added $\mathrm{Zn}(\mu \mathrm{g} / \mathrm{g})$ & - & - & $13 \cdot 6 \S$ & $13.6 \S$ \\
\hline
\end{tabular}

* Basal $\mathrm{Zn}$ content $6.6 \mu \mathrm{g} / \mathrm{g}$ by analysis.

† Salt mixture (Greenfield et al. 1969) without zinc carbonate ( $\mathrm{g} / \mathrm{kg}$ diet): calcium carbonate $10 \cdot 2$, calcium hydrogen phosphate $16 \cdot 2$, disodium hydrogen phosphate $9 \cdot 2$, potassium chloride $10 \cdot 2$, magnesium sulphate $3 \cdot 5$, manganese sulphate 0.22 , ferric citrate 0.22 , copper sulphate 0.019 , potassium iodate 0.0012 .

\$ Vitamin mixture without folate $(\mathrm{mg} / \mathrm{kg}$ diet): calcium pantothenate 19 , thiamin hydrochloride $3 \cdot 8$, pyridoxine hydrochloride $8 \cdot 5$, nicotinamide 24 , biotin 0.95 , vitamin $B_{12} 0.05$, riboflavin 14 , retinyl acetate (as retinol equivalents) $2 \cdot 1$, vitamin $D_{2} 0 \cdot 0075$, menadione $9, \alpha$-tocopherol 250 .

$\S$ Added as the carbonate. Total dietary $\mathrm{Zn} 20 \cdot 2 \mu \mathrm{g} / \mathrm{g}$.

\section{ANIMALS AND METHODS}

Female Norwegian Hooded rats were maintained on a commercial laboratory diet until $110 \mathrm{~d}$ of age, when they were allocated to one of four dietary regimens (see Table 1). Each group consisted of animals of similar mean weight. They were housed singly in plastic and stainless-steel cages, thus avoiding $\mathrm{Zn}$ coatings. Wire-bottoms were used to reduce access to folate through coprophagy. Tap water for drinking was replaced by deionized water.

After $21 \mathrm{~d}$ acclimatization to the diets, the animals were mated, and from each dietary group nine animals were allocated to the pregnancy study and nine to the lactation study. A few of the animals in the lactation half of the study which had failed to become pregnant or had aborted or died were excluded from the study. These comprised : two in group A, two in group B and three in group D. There was no particular reason to attribute these occurrences to dietary factors. Body-weights, litter weights and food intakes were recorded daily.

The animals in the pregnant group were killed on day 20 of gestation and maternal blood was taken from the heart into a syringe containing heparin (10 units). Heparinized whole blood $(0.5 \mathrm{ml})$ was preserved in $4.5 \mathrm{ml}$ ascorbic acid $(10 \mathrm{~g} / \mathrm{l})$ for folate assay. Plasma was separated from the remaining blood and $1 \mathrm{ml}$ was preserved with $0 \cdot 1 \mathrm{ml}$ ascorbate $(100 \mathrm{~g} /$ 1) for folate assay; the remainder was stored frozen for subsequent $\mathrm{Zn}$ estimation. Maternal livers and kidneys were also stored frozen for $\mathrm{Zn}$ estimation. Fetal numbers and total fetal weights were recorded.

Lactating animals and their pups were killed at day 20 of lactation, and the dams' tissue samples were collected as for the pregnant animals. Pups' tissues from each litter were pooled for estimations of folate and $\mathrm{Zn}$.

Whole blood and plasma folate concentrations were determined by radioassay (Fuller et al. 1983). Zn content of the diets, and of the livers, kidneys, plasma and fetal tissues, were determined by atomic absorption spectroscopy, using a Pye Unicam model SP9 atomic 
absorption spectrometer with automatic standardization and an air-acetylene flame. Tissue and food samples were freeze-dried, and then digested in concentrated nitric acid (Spectrosol; BDH, Poole, Dorset) before analysis.

Two-way analysis of variance was used for the statistical analyses.

\section{RESULTS}

A large positive effect of raised dietary folate intake in whole blood and plasma folate levels in all groups (pregnant, lactating, and sucking pups) was observed (Table 2). There was also a highly significant positive effect of $\mathrm{Zn}$ on blood folate levels for pregnant and lactating rats, but not for sucking pups, when folate intakes were low (Table 2).

Pregnant rats receiving marginal folate had significantly $(P<0.001)$ higher whole-blood folate concentrations than lactating rats, in both $\mathrm{Zn}$-treatment groups, but the reverse was true for both $\mathrm{Zn}$ groups on a high-folate intake. Plasma folate concentrations of the highfolate group were higher in the lactating than the pregnant animals, but in the low-folateintake groups there were no detectable differences between pregnant and lactating animals.

The $\mathrm{Zn}$ content of the basal diet, analysed by atomic absorption, was $6 \cdot 6 \mu \mathrm{g} / \mathrm{g}$, and the $\mathrm{Zn}$-supplemented diets contained $20 \cdot 2 \mu \mathrm{g} / \mathrm{g}$. In contrast to the very marked effect of the folate supplement on folate status, the effect of the $\mathrm{Zn}$ supplement on $\mathrm{Zn}$ status was less clearcut (Table 3). Significantly lower $\mathrm{Zn}$ concentrations were, however, observed in the livers of pregnant dams $(P<0.05)$ and sucking pups $(P<0.05)$, in the kidneys of pregnant $(P<0.01)$ and in lactating $(P<0.05)$ dams, and in whole fetuses $(P<0.01)$ when the dietary $\mathrm{Zn}$ was at the lower level. The highest tissue $\mathrm{Zn}$ levels were seen in the adequate$\mathrm{Zn}$, high-folate group (group D), e.g. in liver during pregnancy $(P<0.05)$, and in kidney during pregnancy $(P<0.001)$ and lactation $(P<0.01)$ (not shown). No intakerelated differences were observed in plasma $\mathrm{Zn}$ or in hepatic $\mathrm{Zn}$ of the lactating animals, or in renal $\mathrm{Zn}$ of the pups.

The concentration of $\mathrm{Zn}$ in the livers of pregnant and lactating dams and pups showed no significant dietary folate-related differences. However, during pregnancy, renal $\mathrm{Zn}$ levels were significantly lower in the dams on the low-folate diets $(P<0.01)$. In the lactating rats, the low-folate diets again resulted in lower renal $\mathrm{Zn}$ levels $(P<0 \cdot 05)$. No dietary folate effects could be detected on $\mathrm{Zn}$ in the sucking pups' kidneys; nor were plasma $\mathrm{Zn}$ levels affected. Fetal $\mathrm{Zn}$ levels were not significantly affected by folate intake.

Table 4 shows the effects of the four dietary regimens on body- and tissue weights. In pregnancy, high-folate intake decreased weight gain during the second trimester $(P<0.05)$, kidney wet weight $(P<0.01)$ and liver wet weight $(P<0.001)$. Fetal wet weight (total) was significantly increased in the high-folate-intake groups $(P<0.002)$, but this was partly offset by a (non-significant) decrease in fetal numbers in each litter, so that mean weights of individual fetuses were not significantly affected by the dietary folate level. During lactation, the high-folate intake had a beneficial effect $(P<0.02)$ in reducing body-weight loss in dams, but supplemental $\mathrm{Zn}$ had a somewhat deleterious effect $(P<0.05)$. Supplemental $\mathrm{Zn}$ lowered kidney wet weight $(P<0.005)$. When kidney weights were expressed relative to body-weight, supplemental $\mathrm{Zn}$ caused a marginal reduction during lactation $(P<0.05)$, as also did high-folate intakes during either pregnancy $(P<0.05)$ or lactation $(P<0 \cdot 005)$. Supplemental $\mathrm{Zn}$ also increased the liver weights of the sucking pups $(P<0.001)$.

Food intakes (not shown) were, in general, not greatly influenced by diet group; however the low-folate-intake groups did have a significantly higher food consumption than the high-folate-intake groups, during pregnancy $(P<0.05)$. 


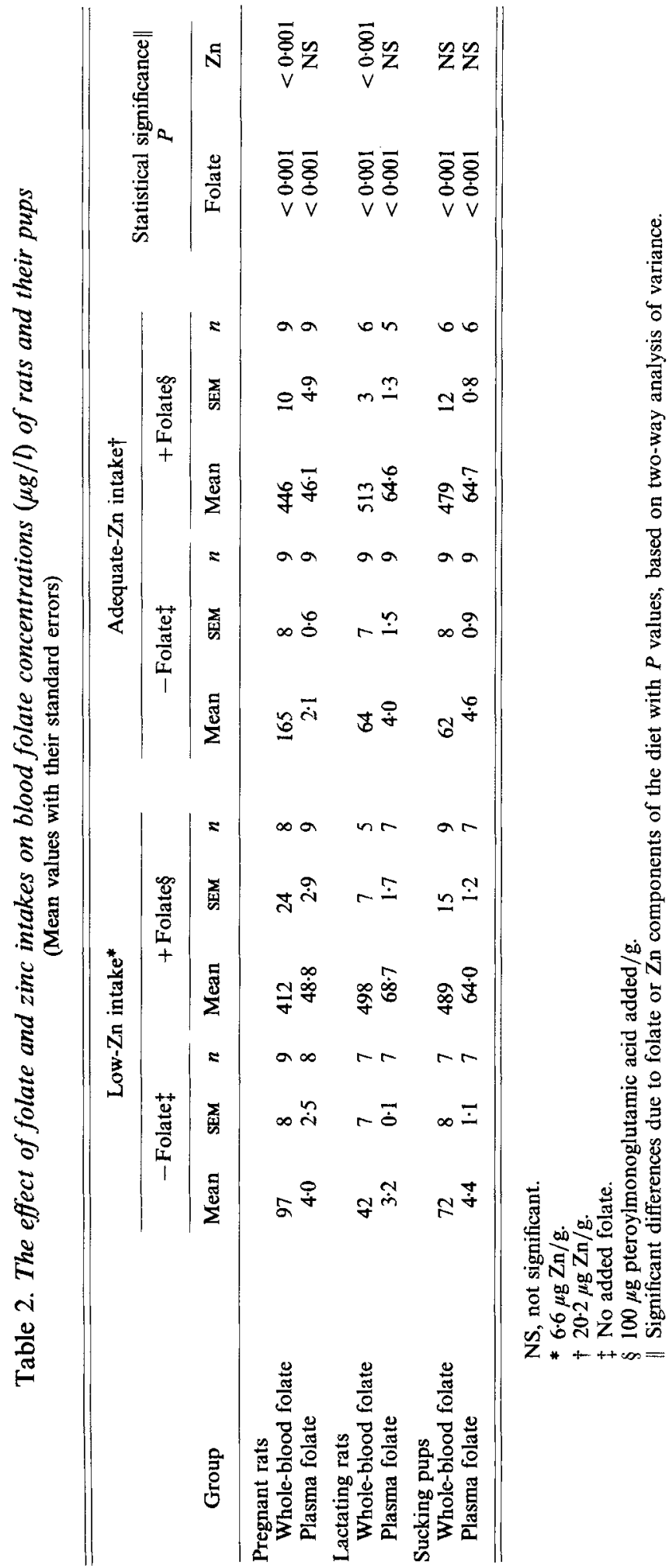




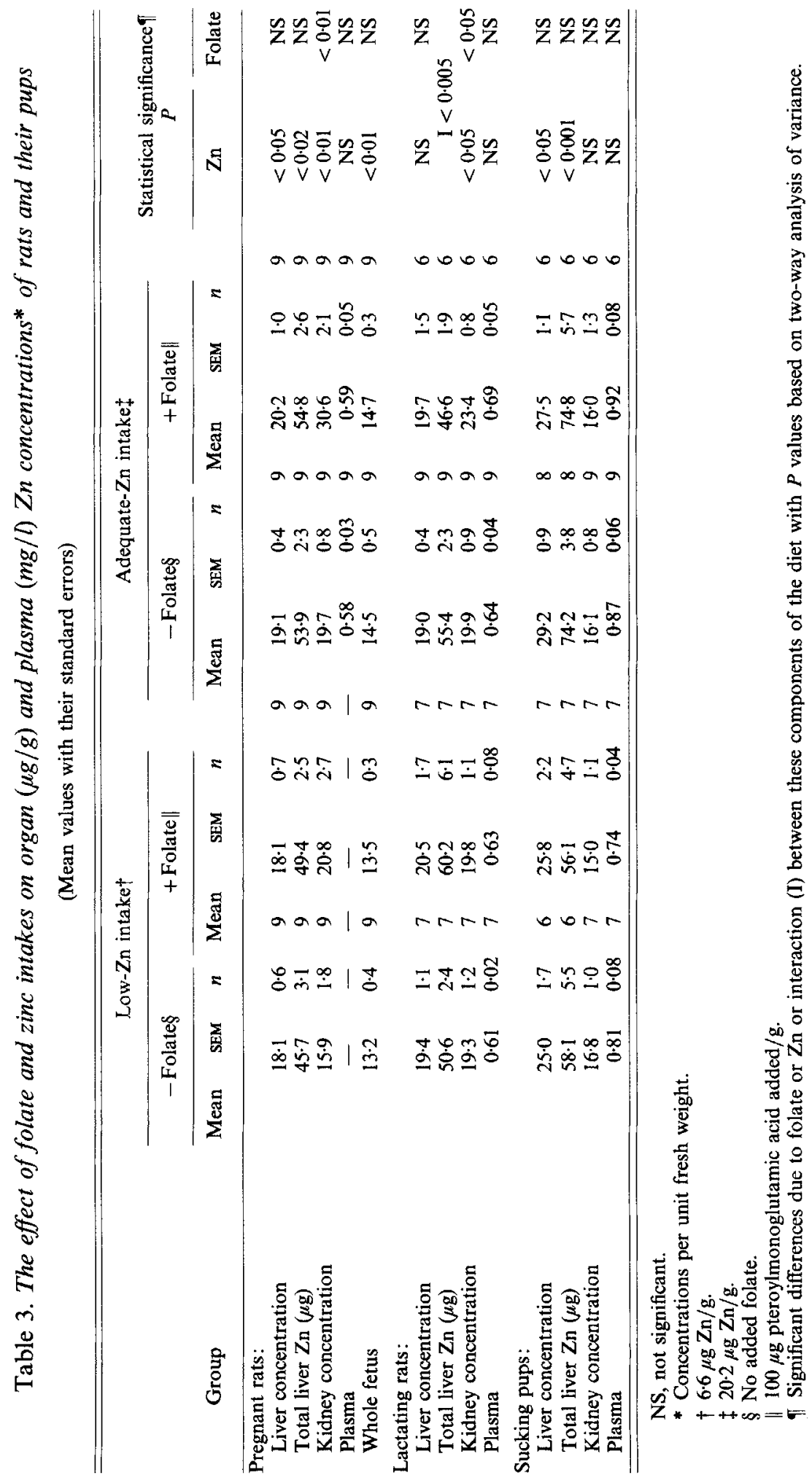




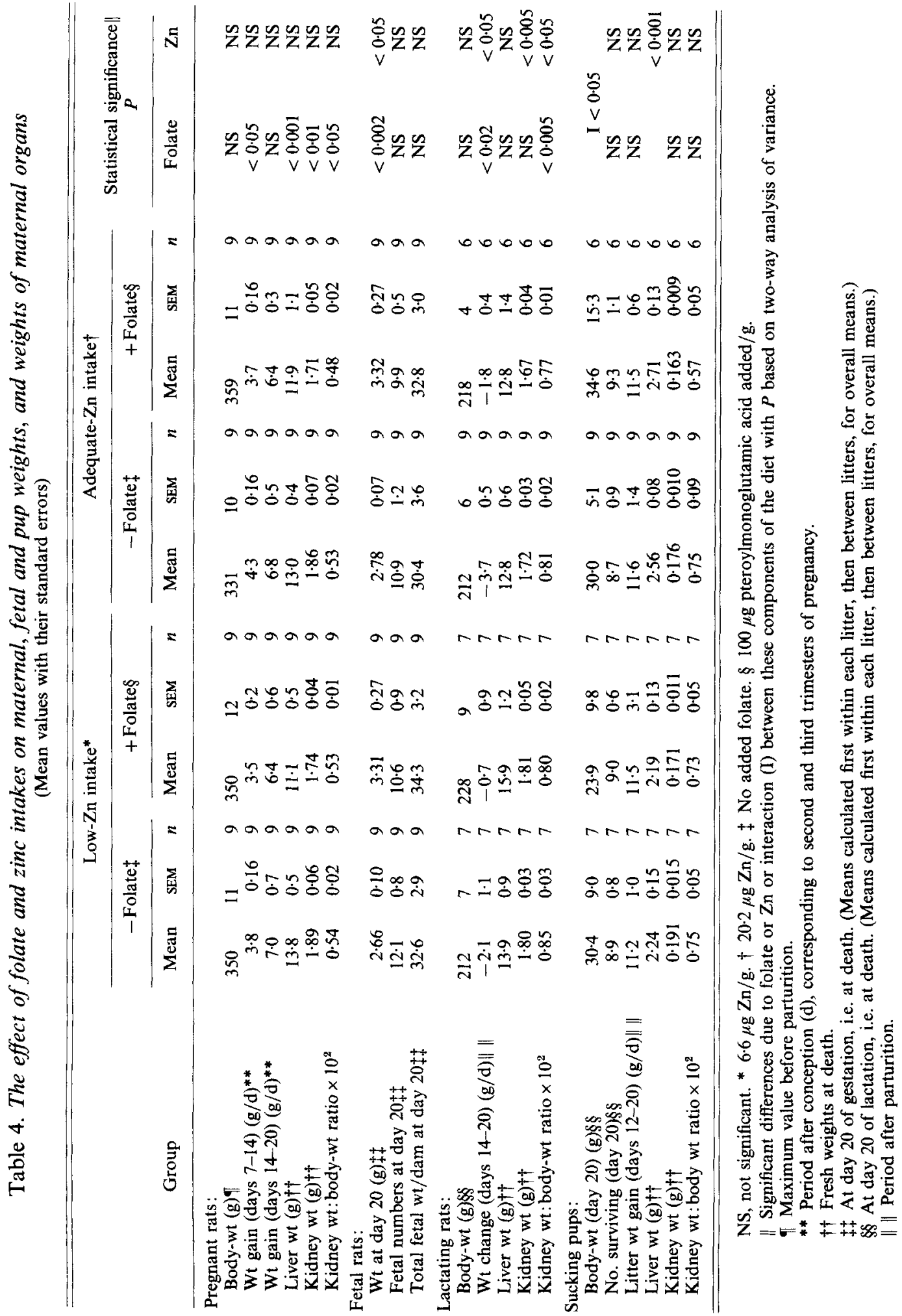


Significant interaction terms between folate-intake and $\mathrm{Zn}$-intake groups generally were not encountered; exceptions being one $(P<0 \cdot 05)$ for the sucking pups' body-weights, and one $(P<0.005)$ for the total $\mathrm{Zn}$ content of the lactating rats' livers.

\section{DISCUSSION}

Folic acid is required for cell multiplication and tissue growth (Morgan \& Winick, 1978). It is therefore not surprising that body-weight changes exhibited a beneficial effect of highfolate intake in the fetuses and in lactating dams. The folate content of the basal diet unfortunately is not precisely known, and indeed it is very difficult, by existing analytical techniques, to obtain really-reliable estimates of very minute amounts of folate in diet components. On the basis of other recent studies (Richardson et al. 1979; Akesson et al. 1982; Hakim et al. 1984), it is likely that the folate content of a purified diet, where the only source of folate is casein, present at $200 \mathrm{~g} / \mathrm{kg}$, is in the range $10-50 \mu \mathrm{g}$ folate $/ \mathrm{kg}$. However, the rat is known to obtain considerable amounts of folate through intestinal floral synthesis and refection which, unless antibiotics are used, may greatly increase the supply of absorbed folate. This, and other details of diet design, may influence the outcome of studies of experimental folate deficiency in a rat model (Walzem et al. 1983). Nevertheless, the observation from the present study, that the folate present in a $200 \mathrm{~g}$ casein $/ \mathrm{kg}$ diet can support a perfectly satisfactory outcome of reproduction in Norwegian Hooded rats, helps to place in perspective parallel observations on folate requirements of rats during reproduction (Morgan \& Winick, 1978; Baker et al. 1984).

Paradoxically, body-weight gains and liver and kidney weights in the pregnant dams were somewhat smaller in the high-folate-intake than the low-folate-intake groups. However, this difference was not seen in the fetal weights; it was no more evident in the low$\mathrm{Zn}$-intake group than the adequate- $\mathrm{Zn}$-intake group, and it was not accompanied by reduced tissue $\mathrm{Zn}$ levels in the high-folate-intake groups (Table 3).

A heavy drain on maternal $\mathrm{Zn}$ stores occurs during pregnancy (Herzfeld et al. 1985). By comparison with several other studies in the rat, the $\mathrm{Zn}$ content of the basal, unsupplemented diet in the present study, might have been insufficient for optimum outcome of reproduction, since the requirement has been reported as being greater than $6 \mu \mathrm{g} / \mathrm{g}$ diet, and usually in excess of $10 \mu \mathrm{g} / \mathrm{g}$ (Williams et al. $1973 \mathrm{~b}$; Fosmire et al. 1977; Halas et al. 1982; Herman et al. 1985; Herzfeld et al. 1985). One study (Fairweather-Tait et al. 1985) has, however, recorded paradoxically increased fetal weights in litters of rats fed on a marginal $\mathrm{Zn}$ diet during the later stages of pregnancy. In addition, variations in fetal survival can complicate the interpretation of pregnancy-outcome studies (Cunnane, 1982). In the present study, $20 \mu \mathrm{g} \mathrm{Zn/g}$ diet was chosen as an 'adequate' level, on the basis of literature values for rodent $\mathrm{Zn}$ requirements (Greenfield et al. 1969; Clarke et al. 1977). It was not our intention to provide a generous excess of $\mathrm{Zn}$, since any competitive interaction with folate seems more likely to become evident at relatively low $\mathrm{Zn}$ intakes. There was no clearcut advantage of $20 \mu \mathrm{g} \mathrm{Zn}$ over $6 \mu \mathrm{g} / \mathrm{g}$ diet, either for pregnancy weight gain, or for fetal weights or numbers at day 20 of gestation. Effects of $\mathrm{Zn}$ on organ weights were variable and difficult to interpret. The $\mathrm{Zn}$ concentration in these organs was not grossly depressed in the marginal- $\mathrm{Zn}$-intake groups but it was, nevertheless, significantly enhanced by supplementary $\mathrm{Zn}$ for the following tissues: pregnant rats' livers and kidneys; lactating rats' kidneys, and sucking pups' livers. The beneficial effect of the higher $\mathrm{Zn}$ intake on tissue $\mathrm{Zn}$ concentration appeared, however, to be smaller than that recorded in other similar studies (Fosmire et al. 1977; Halas et al.1982; Herman et al. 1985). Sparing effects on fetal growth and fetal $\mathrm{Zn}$ have been described at very low maternal $\mathrm{Zn}$ intakes (Fosmire et al. 1977; Masters et al. 1983) but not at marginally-sufficient intakes, comparable to the 
conditions of the present study. It is clear, nevertheless, that Norwegian Hooded rats can achieve generally satisfactory tissue $\mathrm{Zn}$ levels, pregnancy outcome and pup development, even when dietary $\mathrm{Zn}$ (from the casein component of the diet) is present at only $6 \mu \mathrm{g} / \mathrm{g}$ diet.

The absence of evidence, in the present study, for any deleterious interaction between dietary pteroylmonoglutamic acid and dietary $\mathrm{Zn}$, either at the level of maternal, fetal or pup growth, or at that of tissue $\mathrm{Zn}$ concentrations, clearly contrasts with the evidence, from human studies, of an inhibitory effect of large doses of pteroylmonoglutamic acid on intestinal Zn absorption (Milne et al. 1984; Ghishan et al. 1986; Lukaski et al. 1986; Sandstead et al. 1987; Simmer et al. 1987). The concentration of pteroylmonoglutamic acid in the supplemented diet of the present study was large enough to have provided the equivalent of at least $100-300 \mathrm{mg} / \mathrm{d}$ to a human, which would clearly be a very high intake. It is conceivable that the rat is, for some reason, better able to counteract an intralumen interaction of these two nutrients than human subjects are. Whereas two published rat studies from other laboratories have documented an inhibitory effect of folate on $\mathrm{Zn}$ absorption (McMaster et al. 1985; Ghishan et al. 1986), two others (Pallauf \& Kirchgessner, 1972; Wada et al. 1986) failed to detect such an interaction in rats' intestine.

More importantly, an apparently deleterious interaction at the lumen level may fail, for reasons associated with the efficient homeostasis of nutrients in vivo, to be translated into a significant effect on tissue $\mathrm{Zn}$ concentrations and functional indices of $\mathrm{Zn}$ status. Apart from a single report (Simmer et al. 1987), it is not clear to what extent a $\mathrm{Zn}$-folate interaction in the human intestine can affect Zn economy at the tissue level, and indeed no functional results of the interaction have yet been documented. The magnitude of the requirement for $\mathrm{Zn}$ during human pregnancy also remains uncertain (Tuttle et al. 1985).

The observation of a positive effect of supplementary $\mathrm{Zn}$ on whole-blood folate is an intriguing but unexplained observation. In this context, Williams et al. (1973a) found that Zn-deficient sucking rat pups accumulate less folic acid in their livers than Zn-replete ones; Tamura et al. (1978) showed that intestinal $\gamma$-glutamyl hydrolase (conjugase; $E C$ 3.4.22.12) in man is a Zn-dependent enzyme and Tamura et al. (1987) found that hepatic methionine synthase activity is increased in $\mathrm{Zn}$-deficient rats. These observations point towards altered folate metabolism in $\mathrm{Zn}$ deficiency, which may affect tissue folate levels. It will be important to determine whether the $\mathrm{Zn}$ effect on erythrocyte folate, seen in the present study, is confined to one or two tissues, or whether it represents a generally positive effect on whole-body folate status.

In practical terms, the fact that folate deficiency during human pregnancy apparently can compromise the development of the fetus, at least with respect to birth weight (Baumslag, 1970; Iyengar \& Rajalakshmi, 1975; Rolschau et al. 1979; Blot et al. 1981; Tchernia et al. 1982 ), is a strong argument for ensuring that folate deficiency during pregnancy is not allowed to remain untreated. This may, of course, require maternal supplementation.

The results of the present study, if they can be extrapolated to human populations, provide some degree of reassurance that, despite the obviously serious implications of a reaction between $\mathrm{Zn}$ and pteroylmonoglutamic acid in the intestine, the use of folate supplements during pregnancy may, in practice, be harmless. With the present state of knowledge, however, it would still appear to be prudent to ensure that those pregnant women who receive prophylactic folate supplements should receive appropriate monitoring, and if necessary, $\mathrm{Zn}$ supplementation, to eliminate any possibility of an iatrogenic $\mathrm{Zn}$ deficiency, and to ensure that optimum $\mathrm{Zn}$ supplies are provided to the vulnerable growing fetus. 
The authors are indebted to Miss $\mathrm{H}$. Smith for assistance with the animals, and to $\mathrm{Dr}$ T. J. Cole for assistance with statistical analysis.

\section{REFERENCES}

Akesson, B., Fehling, C., Jagestad, M. \& Stenram, U. (1982). British Journal of Nutrition 47, 505-520.

Albert, A. (1953). Biochemical Journal 54, 646-654.

Baker, H., Thind, I. S., DeAngelis, B., Feingold, S. \& Frank, O. (1984). Nutrition Reports International 30, 587-596.

Baumslag, N., Edelstein, T. \& Metz, J. (1970). British Medical Journal i, 16-17.

Blot, I., Papiernik, E., Kaltwasser, J. P., Werner, E. \& Tchernia, G. (1981). Gynecology and Obstetrics Investigation 12, 294-304.

Clarke, H. E., Coates, M. E., Eva, J. K., Ford, D. J., Milner, C. K., O'Donaghue, P. N., Scott, P. P. \& Ward, R. J. (1977). Laboratory Animals 11, 1-28.

Cunnane, S. C. (1982). British Journal of Nutrition 47, 495-504.

Fairweather-Tait, S. J., Wright, A. J. A., Cooke, J. \& Franklin, J. (1985). British Journal of Nutrition 54, 401-413.

Fosmire, G. J., Greeley, S. \& Sandstead, H. H. (1977). Journal of Nutrition 107, 1543-1550,

Fuller, N. J., Bates, C. J. \& Scott, K. J. (1983). Clinica Chimica Acta 131, 343-348.

Ghishan, F. K., Said, H. M., Wilson, P. C., Murrell, J. E. \& Greene, H. L. (1986). American Journal of Clinical Nutrition 43, 258-262.

Greenfield, M., Briggs, G. M., Watson, R. H. J. \& Yudkin, J. (1969). Proceedings of Nutrition Society 28, 43A.

Hakim, A. M., Arrieta, M. J., Cooper, B. A. \& Pappins, H. M. (1984). Journal of Neurochemistry 42, 1582-1587.

Halas, E. S., Wallwork, J. C. \& Sandstead, H. H. (1982). Journal of Nutrition 112, 542-551.

Herman, Z., Greeley, S. \& King, J. C. (1985). Nutritional Research 5, 211-219.

Herzfeld, G. A., Reynolds, L. A. \& Ritchey, S. J. (1985). Nutrition Reports International 31, 849-856.

Iyengar, L. \& Rajalakshmi, K. (1975). American Journal of Obstetrics and Gynecology 122, 332-336.

Lukaski, H. C., Bolonchuk, W. W. \& Milne, D. B. (1986). Federation Proceedings 45, 973.

McMaster, D., Ewing, A. S., Erwin, C., McBriar, D. L. \& Love, A. H. G. (1985). Nutritional Research Suppl. 1, 267-270.

Masters, D. G., Keen, C. L., Lonnerdal, B. \& Hurley, L. S. (1983). Journal of Nutrition 113, $905-912$.

Milne, D. B., Canfield, W. K., Mahalko, J. R. \& Sandstead, H. H. (1984). American Journal of Clinical Nutrition $39,535-539$.

Morgan, B. L. G. \& Winick, M. (1978). British Journal of Nutrition 40, 529-533.

Mukherjee, M. D., Sandstead, H. H., Ratnaparkhi, M. V., Johnson, L. K., Milne, D. B. \& Strelling, H. P. (1984). American Journal of Clinical Nutrition 40, 496-507.

Pallauf, J. \& Kirchgessner, M. (1972). International Journal of Vitamin and Nutrition Research 42, 555-564.

Richardson, R. E., Healy, M. J. \& Nixon, P. F. (1979). Biochimica et Biophysica Acta 585, 128-133.

Rolschau, J., Date, J. \& Kristoffersen, K. (1979). Acta Obstetrica et Gynecologica Scandinavica 58, 343-346.

Sandstead, H., Cherry, F., Bazzano, G., Johnson, L., Bunce, H., Milne, D., Mahalko, J. \& Batson, H. (1987). Federation Proceedings 46, 748.

Simmer, K., Iles, C. A., James, C. \& Thompson, R. P. H. (1987). American Journal of Clinical Nutrition 45, $122-125$.

Simmer, K. \& Thompson, R. P. H. (1985). Acta Paediatrica Scandinavica 319, Suppl., 158-163.

Tamura, T., Kaiser, L. L., Watson, J. E., Halsted, C. H., Hurley, L. S. \& Stokstad, E. L. R. (1987). Archives of Biochemistry and Biophysics 256, 311-316.

Tamura, T., Shane, B., Baer, M. T., King, J. C., Margen, S. \& Stokstad, E. L. R. (1978). American Journal of Clinical Nutrition 31, 1984-1987.

Tchernia, G., Blot, I., Rey, A., Kaltwasser, J. P., Zittoun, J. \& Papiernik, E. (1982). Developmental Pharmacology and Therapeutics 4, Suppl. 1, 58-65.

Tuttle, S., Aggett, P. J., Campbell, D. \& MacGillivray, I. (1985). American Journal of Clinical Nutrition 41, 1032-1041.

Wada, L., Keating, S., King, J. C. \& Stokstad, E. L. R. (1986). Federation Proceedings 45, 1081.

Walzem, R. L., Clifford, C. K. \& Clifford, A. J. (1983). Journal of Nutrition 113, $421-429$.

Williams, R. B., Demertzis, P. \& Mills, C. F. (1973b). Proceedings of Nutrition Society 32, 3A.

Williams, R. B., Mills, C. F. \& Davidson, R. J. L. (1973a). Proceedings of Nutrition Society 32, 2A. 